\title{
Work Productivity of People with Physical Disabilities During the Pandemic COVID-19 in DIY
}

\author{
Sumarjo Sumarjo ${ }^{1, *}$ Ahmad Nasrulloh ${ }^{1}$, Sumaryanto Sumaryanto ${ }^{1,}$ Farid Imam \\ Nurhadi $^{1,}$ Yudik Prasetyo ${ }^{1,}$ Rifky Riyandi Prastyawan ${ }^{1}$ \\ ${ }^{1}$ Department of Sport Science, Faculty of Sport Sciences, Universitas Negeri Yogyakarta \\ ${ }^{*}$ Corresponding author.Email: sumarjo@uny.ac.id
}

\begin{abstract}
This study aims to determine the work productivity of people with physical disabilities during the covid 19 pandemic in DIY. This research is qualitative and quantitative descriptive research with a survey approach. The sample in this study will be taken from the existing population using "purposive sampling" namely male and female sex, age 20-30 years, and quadriplegic only one limb is paralyzed at the bottom so that a sample of 20 is obtained. Data collection using a questionnaire to determine the work productivity of people with disabilities consists of five influencing factors, namely: 1) motivation, 2) knowledge, 3) skills, 4) attitudes, and 5) independence. The data analysis technique in this study used descriptive quantitative data analysis techniques. The method of calculating data analysis is to find the magnitude of the relative frequency of the percentage. Determination of categories in the assessment of the management of the results of scoring research or assessments with conversion criteria. The results of the research on the five indicators of work productivity, namely the motivation indicator can be categorized as very high and high with a value of $39.3 \%$. The knowledge indicator is included in the very good category with a value of $42.9 \%$. Most of the skill indicators are in the high category with a value of $42.9 \%$. Attitude indicators are also mostly included in the high category with a value of $42.9 \%$. While the independence indicator is included in the high category with a percentage value of $46.4 \%$. Based on these data, it can be concluded that the overall work productivity of people with physical disabilities during the COVID-19 pandemic in DIY can be categorized as high with a percentage value of $60.7 \%$.
\end{abstract}

Keywords: work productivity, quadriplegic, pandemic, covid 19.

Keywords: Work Productivity, Quadriplegic, Pandemic, Covid 19

\section{INTRODUCTION}

At this time the Indonesian people focus on improving the quality of life and human resources in preparation for moving towards an advanced and sustainable society. Important aspects in supporting the creation of quality human resources include education and health. The national priority in the health sector is health development to improve the health and nutrition status of the community (Rahmawati et al., 2019). Apart from health, another important aspect is improving the quality of education which is very important in development activities. Public health programs give priority to efforts to improve public and family health and prevent disease. Health development is an integral part of the development of human resources (HR), to achieve the development of an advanced, independent, and physically and mentally prosperous nation. Human resource development starts from the time you are in the womb, even long before(Halawa et al., 2019).

The strategy for empowering people with disabilities is an effort that is carried out continuously to achieve the common goal of making people with disabilities empowered. The empowerment process includes awareness, capacity building, and empowerment. Persons with disabilities are part of human diversity and have human rights, as well as differences in gender, skin color, ethnicity, nation, race, and religion. (Poerwanti, 2017). The awareness stage is carried out by forming a positive self-concept or getting rid of mental blocks through training in the formation of self-concept/self-motivation and recognizing selfpotential. The process of increasing self-capacity and empowerment by conducting participatory activities through training. 
Implementation This research stems from several problems related to improving community welfare to increase work productivity for physically disabled people through public education. Even though it has received legal guarantees related to equality of people with disabilities, what is still a problem is the lack of job opportunities, discrimination against minorities with disabilities in society is still high, accessibility to public transportation and public facilities for disabled groups is still difficult. (Ratnawati et al., 2019).

Business to improve public health is the main program to improve the quality of family life through public education. The role of the family and school becomes important, as the realization of the ideas formulated in the national development goals. The Healthy Living Community Movement (GERMAS) is the main choice in realizing a better public health degree by government programs. Germas is a systematic and planned action that is carried out jointly by all components of society with awareness, willingness, and ability, and healthy behavior to improve the quality of life (Kemenkes RI, 2016). The realization of a quality generation for the development of the nation and state, including for persons with disabilities. (Pioh et al., 2017).

The struggle to get recognition of the rights and potentials for persons with disabilities has long been done by disability leaders as well as from general public figures. The business begins by changing the paradigm of the charity approach to an approach based on human rights and the potential to play a role in society or a social approach. The social approach of persons with disabilities has equal opportunities in all aspects of life, such as education, employment, and participation in all community activities. Persons with disabilities have the same right to attend regular schools called inclusive education(Triutari, 2014). SOne of the basic human rights, namely education, must be implemented at all levels in the form of inclusive education and is no longer exclusive as in special schools (Sukadari, 2019).

The people who have not yet entered working age, children and adolescents; or for those who are no longer working (retired) or of old age, they are socially productive, namely having activities, such as school or college for children and adolescents, and social service activities for the elderly. The five dimensions of health influence each other in realizing the level of health in a person, group, or community. That is why health is holistic or comprehensive. Meanwhile, physical disability is defined as patients who experience incomplete physical members such as amputations, bone defects, muscle joint defects, limbs, arms, and paralysis. (Pioh et al., 2017). Apsari \& Mulyana, (2018) stated that there are three main obstacles related to opportunities for people with disabilities, namely community prejudice, negative perceptions, and limited company funds in providing access for workers with disabilities.
Based on 2017 Sakernas data, the national workingage population with disabilities is $21,930,529$ people. Of the total data, including the labor force as many as $11,224,673$ people (51.18 percent), for the disabled workforce who work as many as 10,810,451 (96.31 percent) and open unemployment as many as 414,222 people (3.69 percent). While those who are not in the workforce with disabilities are 10,705,856 (48.82 percent). Data on disabilities who are in school are 206,163 people (1.93 percent), 5,911,017 people (55.21 percent) take care of the household, and 4,588,676 people (42.86 percent) in others. (Central Bureau of Statistics, 2019). The data shows that there is still $3.69 \%$ unemployment for disability nationally, so the role of the government and institutions, as well as disability observers, is still very much needed to support productivity improvement programs for people with disabilities. Data for Persons with Disabilities in Yogyakarta in 2020 amounted to 27,129 people, while people with disabilities were 6,488 people (http://bappeda.jogjaprov.go.id, 2021).

Empowerment measures to increase community capacity can make them more empowered, in the sense of being able to do something useful in community development. As a result, they are very easily angry with others and even at themselves. Greenspan, quoted in Poerwanti (2017), said that people with disabilities are very concerned about body image, acceptance from their friends, freedom, self-acceptance, and achievement. People with disabilities have the potential and willingness to change for the better by the potential of natural resources and local wisdom around them.

The community's perception of people with disabilities that have been ingrained for centuries is difficult to remove. For example, there are students with disabilities who are refused to live in a boarding house, because the owners think that the presence of people with disabilities will bring disaster to their business. According to Istifarroh, \& Nugroho (2014), the factor that causes companies not to employ people with disabilities is that companies do not have sufficient information about where and how companies can recruit workers with disabilities, especially people with disabilities who have skills according to the company's needs. In using air transportation with commercial airplanes, persons with disabilities must sign a sick statement, so they are not covered by insurance.

The effort to bridge legal recognition and actual implementation of the rights of persons with disabilities still needs to be fought for, as the struggle of the predecessors in obtaining legal recognition. Implementation of inclusive education, many things can be done. For example, studies on problems of public perception and self-perception of persons with disabilities, development of the education system, education assessment (evaluation) system, 
career/profession with efforts to increase the productivity of people with disabilities to get a better quality of life (Sukadari, 2019). Fuller (2010) states that there are three main obstacles related to opportunities for people with disabilities, namely community prejudice, negative perceptions, and limited company funds in providing access for workers with disabilities. External influences such as family, social environment, and the development of related regulations, especially in local government that can support the productivity of people with disabilities. Sarju's opinion (2021) is that persons with disabilities include those with long-term physical, mental, intellectual, or sensory limitations which in interaction with various barriers can hinder their full and effective participation in society on an equal basis with others.

People's disability comes from English, namely people with different abilities, namely people who have different abilities from normal people both physically and mentally (Purwanta, 2002 in Deswanto, 2004). Training for people with disabilities can be interpreted as giving hope to achieve a more decent and prosperous standard of living. In some countries, it appears that the concern for people with disabilities is quite large in terms of providing training and skills for them (Ndaumanu, 2020). Hernandez (2011) said that the lack of understanding of business actors regarding the potential and benefits of employing workers with disabilities raises doubts about business actors in making decisions to recruit workers with disabilities.

Community term disability is not limited to those with disabilities but the term disability has a more flexible and broad meaning, namely people who have temporary or permanent obstacles in carrying out their daily activities, including pregnant women, children, the elderly, wheelchair users, crutches, visually impaired, deaf and quadriplegic. The provision of public spaces by the government has not yet reached and has not been able to serve the specific needs of disability activities (Deswanto, 2004).

In Estonia, the NGO "Helping Hand" is active and has formed partnerships with several other institutions such as the NGO "Think Estonia" and the NGO "Merimetsa Support Center" to provide education and training in handicrafts for people with disabilities. The NGO "Helping Hand" also has agreements with several companies in Estonia that require labor for some light work. In Indonesia, to develop the independence of people with disabilities through several ways, such as the entrepreneurial efforts of several people with disabilities. In Yogyakarta, a modified motorcycle taxi business has been initiated by people with disabilities for the disabled community and the general public. Ratnawati et al., (2019)motorcycle taxi service labeled Dhifa CT (City Tour and Transport) is managed by people with disabilities. This service is a forum for independence from people with disabilities who want to prove that people with disabilities can enter the world of work and eliminate discrimination for people with disabilities in the world of work.

Efforts to increase the work productivity of people with disabilities have been pursued by the Government of Indonesia through the provision of various skills. For example, in the program at the Rehabilitation Center for the Disabled, people with disabilities are trained to have various skills. Productivity itself is the ability to produce something. The seriousness and participation of various parties to be able to take part in efforts to empower people with disabilities, so that the long-term goal of forming independent entrepreneurs from people with disabilities can be achieved(Novandari \& Suliyanto, 2018). To achieve a high level of productivity, several factors support the formation of high productivity for people with disabilities. These supporting factors include education, skills, attitudes and work ethic, income level, social security, social level, and work climate, motivation, nutrition and health, individual relations, technology, and production. (Poerwanti, 2017). Therefore, researchers are interested in researching how the work productivity of people with physical disabilities during the COVID-19 pandemic in DIY.

\section{METHODS}

This research is qualitative and quantitative descriptive research with a survey approach. This research was conducted at the Integrated Rehabilitation Center for Persons with Disabilities (BRTPD) in 2021 in Pundong District, Bantul Regency, Special Region of Yogyakarta with a population of 42 people. The sample in this study will be taken from the existing population using "purposive sampling". The data collection instrument using a questionnaire to determine the work productivity of people with disabilities consists of four (5) influencing factors, namely: 1) motivation, 2) knowledge, 3) skills, 4) attitudes, and 5) independence. The data analysis technique in this study used descriptive quantitative data analysis techniques. The method of calculating data analysis is to find the relative frequency of the percentage with the following formula (Sudijono, 2009: 40):

$$
P=\frac{F}{N} X 100 \%
$$

$$
\begin{aligned}
& \text { Information: } \\
& \mathrm{P}=\text { percentage sought (relative frequency) } \\
& \mathrm{F}=\text { frequency } \\
& \mathrm{N}=\text { number of respondents }
\end{aligned}
$$

Categorization using Mean and Standard Deviation. According to Azwar (2010: 163) to determine the score criteria using the Norm Reference Assessment (PAN) in Table 1 as follows: 
Table 1. Class Interval

\begin{tabular}{|l|l|l|}
\hline No & \multicolumn{1}{|c|}{ Range } & \multicolumn{1}{c|}{ Category } \\
\hline 1 & $\mathrm{X}>\mathrm{M}+1.5 \mathrm{SD}$ & Very high \\
\hline 2 & $\mathrm{M}+0.5 \mathrm{SD}<\mathrm{X} \mathrm{M}+1.5 \mathrm{SD}$ & Tall \\
\hline 3 & $\mathrm{M}-0.5 \mathrm{SD}<\mathrm{X} \mathrm{M}+0.5 \mathrm{SD}$ & Currently \\
\hline 4 & $\mathrm{M}-1.5 \mathrm{SD}<\mathrm{X} \mathrm{M}-0.5 \mathrm{SD}$ & Low \\
\hline 5 & $\mathrm{X} \mathrm{M}-1.5 \mathrm{SD}$ & Very low \\
\hline \multicolumn{2}{|c}{} & (Source: Azwar, 2010: 163$)$ \\
\hline
\end{tabular}

Information:

$\mathrm{M}=$ Average value (Mean)

$\mathrm{X}=$ Score

$\mathrm{S}=$ Standard Deviation

\section{RESULTS}

The data of this study were analyzed using descriptive analysis by making categorizations. The research data is categorized into 5 categories, namely very high, high, medium, low, and very low. Categorization of data is made based on the mean value and ideal standard deviation. Furthermore, data analysis was carried out on each question item so that it was known the percentage score of each work productivity indicator including motivation, knowledge, skills, attitudes, and independence. The results of data analysis on each indicator are as follows.

\subsection{Motivation}

Motivation data is categorized into 5 categories based on the ideal or theoretical mean and standard deviation. Motivation data was taken using a questionnaire consisting of 15 statement items, each of which had a score of 1,2,3, and 4 . The minimum score was 15 (1x15), the maximum score was $60(4 \times 15)$ so that a score range of 45 was obtained. $(60-15)$. Calculation of the standard deviation (SD), in normally distributed data has 6 standard units, then the SD value of 7.50 is obtained from (45:6), and the theoretical mean value is $37.50(15+60 / 2)$. Categorization for motivation data is presented in the following table:

Table 2. Categorization of Motivation Data

\begin{tabular}{|c|c|c|l|}
\hline Score Interval & Frequency & $\begin{array}{c}\text { Percentage } \\
(\mathbf{\%})\end{array}$ & \multicolumn{1}{|c|}{ Category } \\
\hline$x>48.75$ & 11 & 39.3 & Very high \\
\hline $41.25<$ to $<48.75$ & 11 & 39.3 & Tall \\
\hline $33.75<$ to $<41.25$ & 3 & 10.7 & Currently \\
\hline $26.25<$ to $<33.75$ & 2 & 7.2 & Low \\
\hline$x \leq 26.25$ & 1 & 3.6 & Very low \\
\hline Total & 28 & 100.0 & \\
\hline
\end{tabular}

Source: Primary data processed 2021

Based on the table above, it is known that most of the respondents have very high and high motivation categories, each of which is 11 people (39.3\%). A small proportion of respondents have moderate motivation as many as 3 people $(10.7 \%)$ and low category as many as 2 people $(7.2 \%)$. The least respondents who have very low motivation are 1 person $(3.6 \%)$.
More clearly the results of the categorization of motivational data can be seen in the following diagram:

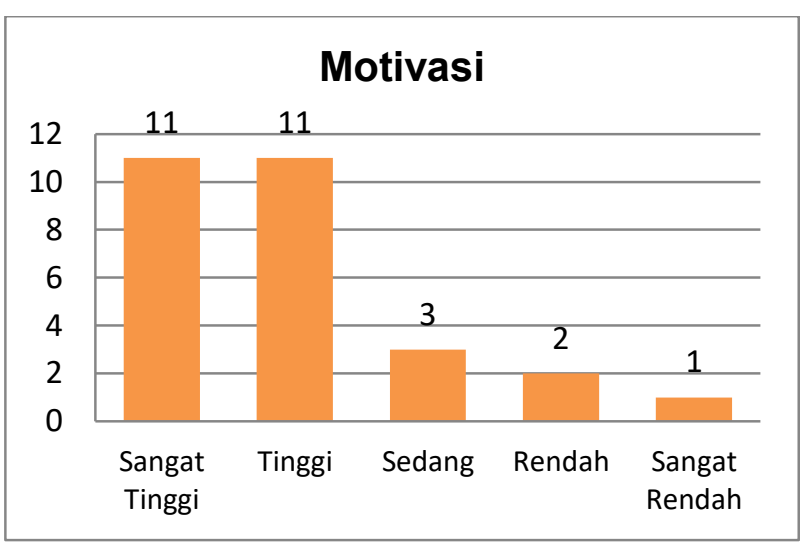

Figure 1. Motivation Category Result Diagram.

Based on the diagram above, it can be concluded that the motivation indicators are in the very high and high categories.

\subsection{Knowledge}

Knowledge data is categorized into 5 categories based on the ideal or theoretical mean and standard deviation. Knowledge data was taken using a questionnaire consisting of 15 statement items, each of which had a score of 1,2,3, and 4 . The minimum score was 15 (1x15), the maximum score was $60(4 \times 15)$ so that a score range of 45 was obtained. $(60-15)$. Calculation of the standard deviation (SD), in normally distributed data has 6 standard units, then the SD value of 7.50 is obtained from (45:6), and the theoretical mean value is $37.50(15+60 / 2)$. Categorization for knowledge data is presented in the following table:

Table 3. Categorization of Knowledge Data

\begin{tabular}{|c|c|c|l|}
\hline Score Interval & Frequency & $\begin{array}{c}\text { Percentage } \\
\mathbf{( \% )}\end{array}$ & Category \\
\hline$x>48.75$ & 12 & 42.9 & Very high \\
\hline $41.25<$ to $<48.75$ & 11 & 29.2 & Tall \\
\hline $33.75<$ to $<41.25$ & 5 & 17.9 & Currently \\
\hline $26.25<$ to $<33.75$ & 0 & 0.0 & Low \\
\hline$x \leq 26.25$ & 0 & 0.0 & Very low \\
\hline Total & 28 & 100.0 & \\
\hline
\end{tabular}

Source: Primary data processed 2021

Based on the table above, it is known that most of the respondents have very high category knowledge as many as 12 people $(42.9 \%)$. Respondents who have high knowledge are 11 people $(39.3 \%)$ and those who have moderate knowledge are 5 people $(17.9 \%)$. There are no respondents who have low or very low knowledge.

More clearly the results of knowledge data categorization can be seen in the following diagram: 


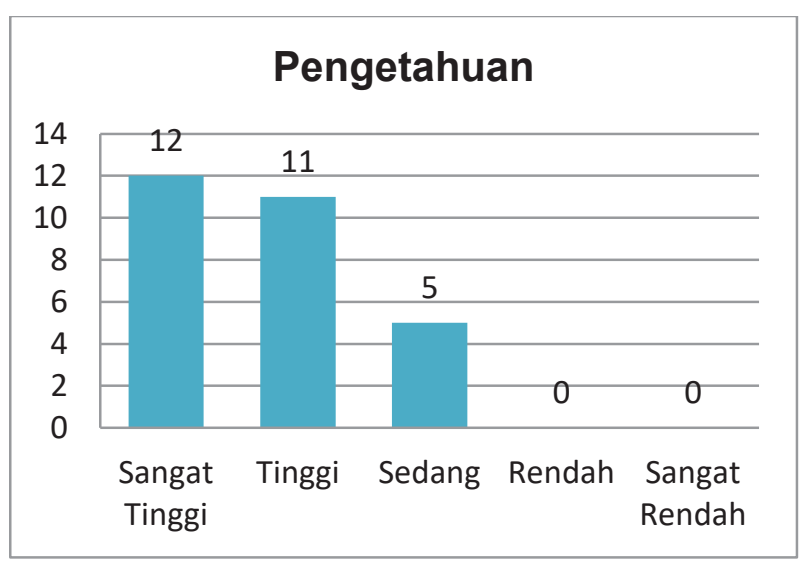

Figure 2. Knowledge Category Result Diagram.

Based on the diagram above, it can be concluded that the knowledge indicator is in the very high category.

\subsection{Skills}

Skill data is categorized into 5 categories based on the mean value and ideal or theoretical standard deviation. Skill data was taken using a questionnaire consisting of 15 statement items, each of which had a score of 1,2,3, and 4 . The minimum score was 15 (1x15), the maximum score was $60(4 \times 15)$ so that a score range of 45 was obtained. $(60-15)$. Calculation of the standard deviation (SD), in normally distributed data has 6 standard units, then the SD value of 7.50 is obtained from (45:6), and the theoretical mean value is $37.50 \quad(15+60 / 2)$. Categorization for skill data is presented in the following table:

Table 4. Categorization of Skills Data

\begin{tabular}{|c|c|c|l|}
\hline Score Interval & Frequency & $\begin{array}{c}\text { Percentage } \\
(\mathbf{\%})\end{array}$ & Category \\
\hline$x>48.75$ & 9 & 32.1 & Very high \\
\hline $41.25<$ to $<48.75$ & 12 & 42.9 & Tall \\
\hline $33.75<$ to $<41.25$ & 4 & 14.3 & Currently \\
\hline $26.25<$ to $<33.75$ & 3 & 10.7 & Low \\
\hline$x \leq 26.25$ & 0 & 0.0 & Very low \\
\hline Total & 28 & 100.0 & \\
\hline
\end{tabular}

Source: Primary data processed 2021

The results of the categorization of skills data are known that most of the respondents have high category skills as many as 12 people (42.9\%). A total of 9 people (32.1\%) have very high skills. A small proportion of 4 people $(14.3 \%)$ have moderate skills and as many as 3 people $(10.7 \%)$ have low skills. There are no respondents who have very low skills.

More clearly, the results of the categorization of skills data can be seen in the following diagram:

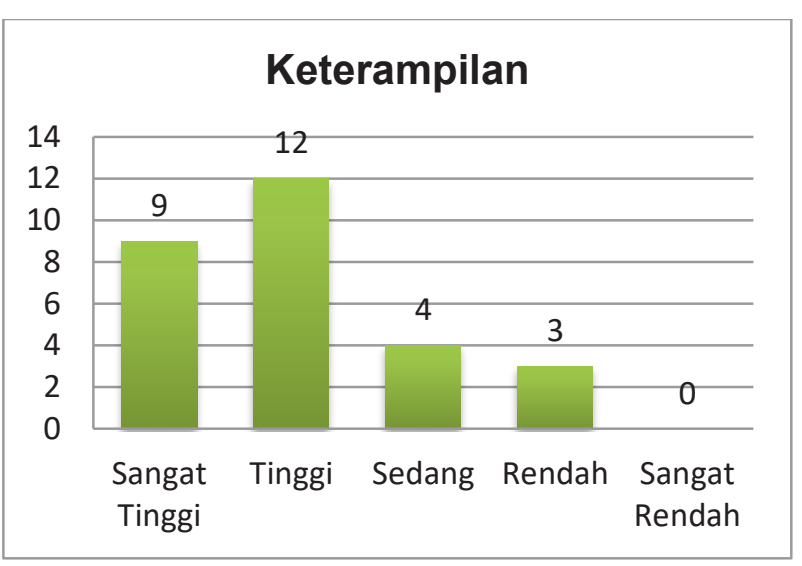

Figure 3. Skills Category Result Diagram.

Based on the diagram above, it can be concluded that the skill indicators are in the high category.

\subsection{Attitude}

Attitude data are categorized into 5 categories based on the ideal or theoretical mean and standard deviation. Attitude data were taken using a questionnaire consisting of 15 statement items, each of which had a score of 1,2,3, and 4 . The minimum score was 15 (1x15), the maximum score was $60(4 \times 15)$ so that a score range of 45 was obtained. $(60-15)$. Calculation of the standard deviation (SD), in normally distributed data has 6 standard units, then the SD value of 7.50 is obtained from $(45: 6)$, and the theoretical mean value is $37.50 \quad(15+60 / 2)$. Categorization for attitude data is presented in the following table:

Table 5. Categorization of Attitude Data

\begin{tabular}{|c|c|c|l|}
\hline Score Interval & Frequency & $\begin{array}{c}\text { Percentage } \\
(\mathbf{\%})\end{array}$ & Category \\
\hline$x>48.75$ & 10 & 35.7 & Very high \\
\hline $41.25<$ to $<48.75$ & 12 & 42.9 & Tall \\
\hline $33.75<$ to $<41.25$ & 6 & 21.4 & Currently \\
\hline $26.25<$ to $<33.75$ & 0 & 0.0 & Low \\
\hline$x \leq 26.25$ & 0 & 0.0 & Very low \\
\hline Total & 28 & 100.0 & \\
\hline
\end{tabular}

Source: Primary data processed 2021

Based on the table above, it is known that most of the respondents have a high category attitude as many as 12 people $(42.5 \%)$. A total of 10 people $(35.7 \%)$ had a high category attitude. A small proportion of respondents as many as 6 people $(21.4 \%)$ have an attitude of moderate category. No one has a low and very low attitude. 
More clearly, the results of attitude data categorization can be seen in the following diagram:

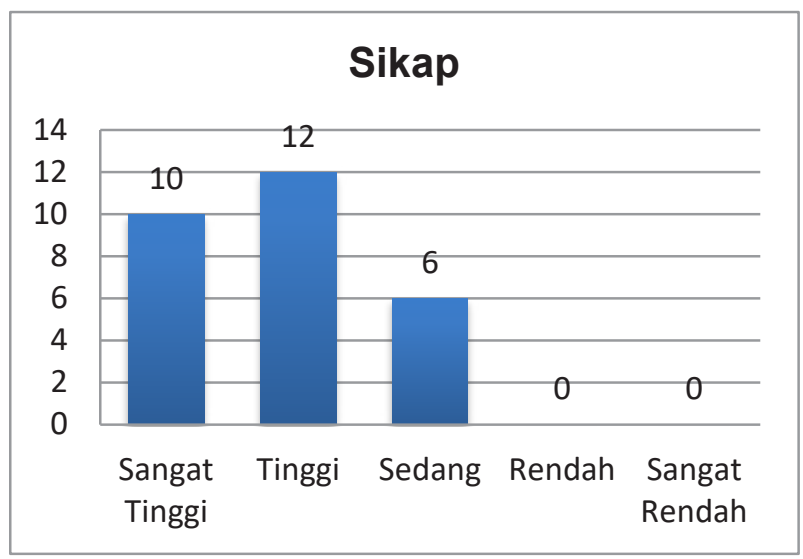

Figure 4. Attitude Category Result Diagram.

Based on the diagram above, it can be concluded that the attitude indicators are in the high category.

\subsection{Independence}

The independence data were categorized into 5 categories based on the ideal or theoretical mean and standard deviation. Independence data was taken using a questionnaire consisting of 15 statement items, each of which had a score of 1,2,3, and 4 . The minimum score was $15(1 \times 15)$, the maximum score was $60(4 \times 15)$ so that a score range of 45 was obtained. $(60-15)$. Calculation of the standard deviation (SD), in normally distributed data has 6 standard units, then the SD value of 7.50 is obtained from (45:6), and the theoretical mean value is $37.50(15+60 / 2)$. Categorization for independence data is presented in the following table:

Table 6. Categorization of Independent Data

\begin{tabular}{|c|c|c|l|}
\hline Score Interval & Frequency & $\begin{array}{c}\text { Percentage } \\
\text { (\%) }\end{array}$ & \multicolumn{1}{|c|}{ Category } \\
\hline$x>48.75$ & 10 & 35.7 & Very high \\
\hline $41.25<$ to $<48.75$ & 13 & 46.4 & Tall \\
\hline $33.75<$ to $<41.25$ & 5 & 17.9 & Currently \\
\hline $26.25<$ to $<33.75$ & 0 & 0.0 & Low \\
\hline$x \leq 26.25$ & 0 & 0.0 & Very low \\
\hline Total & 28 & 100.0 & \\
\hline
\end{tabular}

Source: Primary data processed 2021

The results of data categorization show that most of the respondents have a high category of independence, as many as 13 people (46.4\%). A total of 10 people (35.7\%) had high category independence. A small proportion of respondents as many as 5 people $(17.9 \%)$ had moderate category independence. No one has low and very low independence.
More clearly the results of the categorization of independence data can be seen in the following diagram:

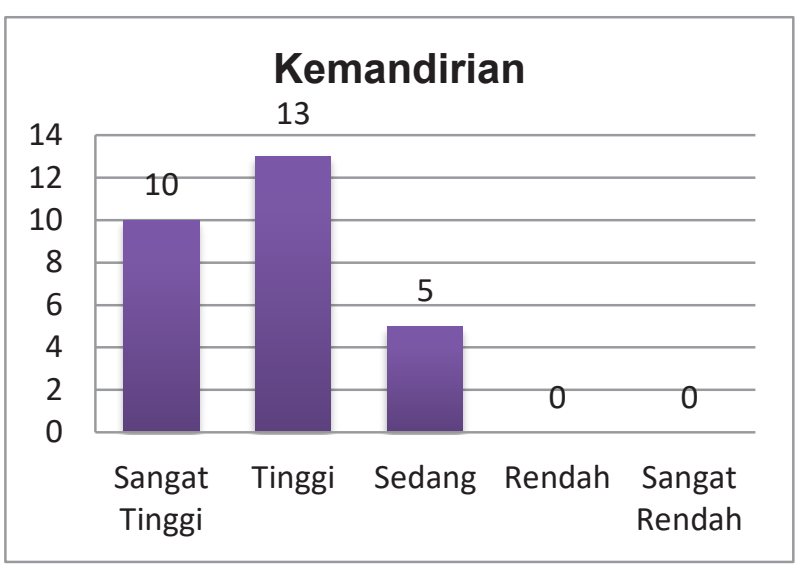

Figure 5. Result Chart for Independence Category.

Based on the diagram above, it can be concluded that the independence indicator is in the high category.

\subsection{Work Productivity (overall)}

Work productivity data is categorized into 5 categories based on the ideal or theoretical mean and standard deviation. Work productivity data is taken using a questionnaire consisting of 75 statement items (out of 5 indicators) each of which has a score of 1,2,3, and 4 . The minimum score is $75(1 \times 75)$, the maximum score is 300 $(4 \times 75)$ so that a score range of $225(300-75)$ is obtained. Calculation of the standard deviation (SD), in normally distributed data has 6 standard units, then the SD value of 37.50 is obtained from $(225: 6)$, and the theoretical mean value is $187.50(75+300 / 2)$. Categorization for work productivity data is presented in the following table:

Table 7. Categorization of Work Productivity Data

\begin{tabular}{|c|c|c|l|}
\hline Score Interval & Frequency & $\begin{array}{c}\text { Percentage } \\
(\%)\end{array}$ & \multicolumn{1}{|c|}{ Category } \\
\hline$x>243.75$ & 7 & 25.0 & Very high \\
\hline $205.25<$ to $<243.75$ & 17 & 60.7 & Tall \\
\hline $168.75<$ to $<206.25$ & 4 & 14.3 & Currently \\
\hline $131.25<$ to $<168.75$ & 0 & 0.0 & Low \\
\hline$x \leq 131.25$ & 0 & 0.0 & Very low \\
\hline Total & 28 & 100.0 & \\
\hline \multicolumn{4}{|c|}{ Source: Primary data processed 2021} \\
\hline
\end{tabular}

The results of data categorization are known that most of the respondents have a high category of work productivity as many as 17 people $(60.7 \%)$. As many as 7 people $(25 \%)$ have very high work productivity and as many as 4 people $(14.3 \%)$ have moderate work productivity. No one has low and very low work productivity.

More clearly the results of the categorization of work productivity data can be seen in the following diagram: 


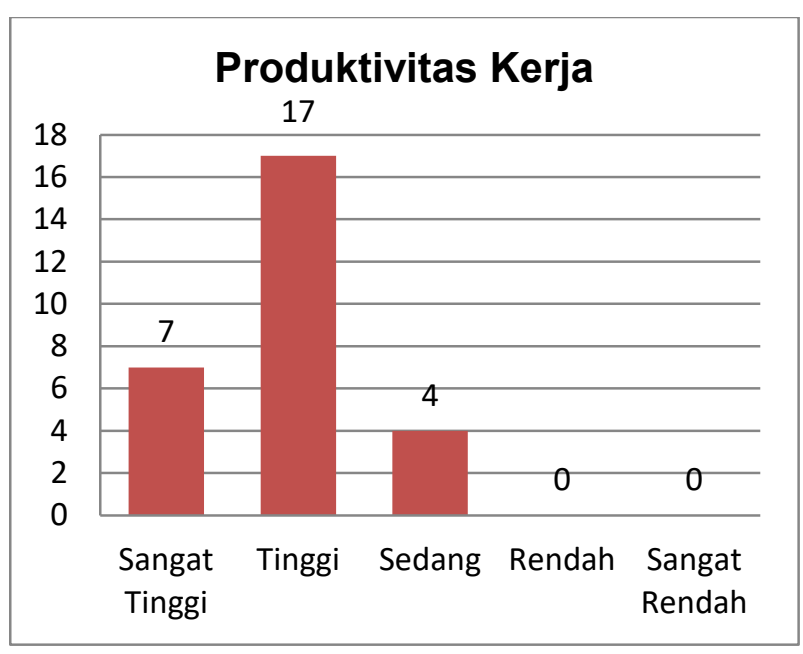

Figure 6. Result Chart for Independence Category.

Based on the diagram above, it can be concluded that overall work productivity is in the high category.

\section{DISCUSSION}

\subsection{Motivation}

Motivation includes psychological and physical factors that cause individuals to act in certain ways at certain times (Kaya, et al., 2015). Motivation is an internal energy force that determines all aspects of individual behavior. It also affects how individuals think, feel, and interact with other individuals. In the sport itself, athletes need motivational interventions for the training process and competitions, even motivation is generally accepted as an important prerequisite to lead athletes to fulfill their potential and performance (Slathia, et al., 2015). Motivation can inspire people to work individually or in groups in such a way as to produce the best results. Based on the opinion above, it can be concluded that motivation is the expulsion of the driving force within a person who is endeavored to generate and ensure the continuity of one's activities, as well as provide direction so that the desired goals can be achieved (Kuranchie-Mensah \& Tawiah, 2016). From the data analysis, most of the motivation indicators can be categorized as very high and high with a value of $39.3 \%$, meaning that the motivation of people with physical disabilities during the COVID-19 pandemic is in the very high category.

\subsection{Knowledge}

Knowledge is one of the domains in the cognitive aspect. Knowledge can be defined as the addition of information to a person after sensing an object. Automatically, the process of sensing to produce knowledge is influenced by the perception and intensity of attention to the object. Most of a person's knowledge is obtained through the sense of sight and the sense of hearing (Notoatmodjo, 2012). The factors that influence knowledge include education, information/mass media, occupation, environment, experience, age, social, culture, and economy. Based on some of the opinions above, it can be concluded that knowledge is everything that is known to someone who is obtained through sensing or interacting with certain objects in the surrounding environment. (Notoatmodjo (2012). Knowledge is a treasure trove of mental wealth that directly or indirectly contributes to enriching life. Each knowledge has specific characteristics about what (ontology), how (epistemology) and for what (axiology). The knowledge that a person has affects his behavior, the better a person's knowledge, the better his behavior will be (Rajaratenam, et al., 2014). Based on the results of the study, it can be seen that the indicators knowledge is included in the very high category with a value of $42.9 \%$, meaning that the knowledge of people with physical disabilities during the covid $19 \mathrm{~s}$ pandemic is in the very high category.

\subsection{Skills}

Skills are the ability to operate work easily and quickly, this understanding usually tends to psychomotor activities (Sulistyowati, 2019). Skill is the ability to operate work more easily and precisely. This definition of skills tends to lead to psychomotor activity (Melati, 2016). Skill is the ability to operate work easily and carefully. This understanding usually tends to psychomotor activity. Skills can also be interpreted as activities that require practice or can be interpreted as implications of activities (Goldon, 2010). According to Saud (Wulandari \& Kurniah), the skills of presenting information verbally are systematically organized to show the relationship between one part and another, for example between cause and effect, definition by example, or with something that is not yet known. Based on some of the opinions above, it can be concluded that skill is skill or skill in doing something so that in doing something skill is required so that a work process can run well to achieve that goal. Based on research results most of the skills are in the high category with a value of $42.9 \%$, meaning that the skills of people with physical disabilities during the COVID-19 pandemic are in the high category.

\subsection{Attitude}

Attitude is a favorable or unfavorable evaluative reaction to an object, showing a person's beliefs, feelings, or behavioral tendencies (Sarwono and Meinarno, 2011). Attitude is a state of mental readiness that is learned and organized according to experience and causes a special influence on people reaction person towards people, objects, and situations with whom he relates (Sembiring, 2018). Attitude is the tendency to respond positively or negatively to someone or something in their environment 
(Sya'baniah, 2019). Toto (2018) if we have a positive work attitude, we will work longer and harder to get the results as expected. Attitudes encourage us to act in specific ways in specific contexts. That is attitudes influence behavior on many different levels. In contrast to values that express an overarching belief that influences behavior in all situations. Notoatmodjo (2014), attitude consists of 3 components that support each other, namely cognitive, affective and conative components. Attitude is essentially a person's tendency to state whether it is pleasant or unpleasant, which reflects how he feels about people, objects, or events in his environment. Based on the results research on attitude indicators obtained results mostly included in the high category with a value of $42.9 \%$, meaning that the attitude of persons with physical disabilities during the COVID19 pandemic was in the high category.

\subsection{Independence}

The word "independent" is taken from two terms whose meanings are often equated with one another, namely autonomy and independence because the differences between the two terms are very thin. Independence in the sense of freedom, in general, refers to the ability of individuals to carry out their life activities, without depending on the help of others (Nurhayati, 2015). Bungsu, et al., (2018), independence is the basic word of independence which means to stand alone, which is a situation where it allows a person to organize and direct himself according to his level of development. Independence is an attitude that allows a person to do something that happens because of his impulse, the ability to self-regulate to solve problems, and be responsible for the decisions he makes (Toto, 2018). The factors that influence independence are genes, parenting patterns, education in schools, and life in society (Ali \& Asrori, 2010). Based on the results the independence indicator is in the high category with a percentage value of $46.4 \%$, meaning that the attitude of people with physical disabilities during the COVID-19 pandemic is in the high category.

\subsection{Work Productivity}

Comparison in arithmetic between the amount produced and the amount of each source used during production takes place. Increased productivity can only be realized from an increase in efficiency (time-materiallabor) and work systems, production techniques, and an increase in the skills of the workforce. Employee work productivity according to Gaol (2014) is an employee's achievement in the work environment. By definition of work, productivity is a comparison between the results achieved (output) with the overall resources (inputs) used per unit of time. It can be concluded that productivity is a person's ability to manage and utilize the resources they have to forget optimal output or results in the context of carrying out the tasks assigned to him and achieving predetermined work results. Based on research results The percentage value of work productivity can be categorized as high with a percentage value of $60.7 \%$, meaning that the work productivity of people with physical disabilities during the COVID-19 pandemic is categorized as high.

\section{CONCLUSION}

Work productivity of persons with physical disabilities during the covid 19 pandemic in DIY in this study were assessed based on 5 indicators, namely motivation, knowledge, skills, attitudes, and independence. The results of the research on the five indicators of work productivity, namely the motivation indicator can be categorized as very high. The knowledge indicator is included in the very good category with a value of $42.9 \%$. Most of the skill indicators are in the high category with a value of $42.9 \%$. Attitude indicators are also mostly included in the high category with a value of $42.9 \%$. While the independence indicator is included in the high category with a percentage value of $46.4 \%$. Based on these data, it can be concluded that the overall work productivity of people with physical disabilities during the COVID-19 pandemic in DIY can be categorized as high with a percentage value of $60.7 \%$.

\section{REFERENCES}

[1] Andayani, A., \& Afandi, M. (2019). Pemberdayaan dan pendampingan komunitas penyandang disabilitas dalam mengakses pendidikan tinggi. Aplikasia: Jurnal Aplikasi Ilmu-Ilmu Agama, 16(2), 153.

[2] Gaol, J. L. (2014). Human capital manajemen sumber daya manusia. Jakarta: Penerbit PT. Gramedia Widiasarana Indonesia.

[3] Halawa, O., Nurhayati, S., \& Rochana, S. (2019). Pemberdayaan untuk meningkatkan taraf hidup di Kampung Adat Cireundeu Cimahi. Comm-Edu (Community Education Journal), 2(3), 210.

[4] Hernandez, B., Chen, B., Araten-Bergman, T., Levy, J., Kramer, M., \& Rimmerman, A. (2012). Workers with disabilities: Exploring the hiring intentions of nonprofit and for-profit employers. Employee Responsibilities and Rights Journal, 24(4), 237-249.

[5] Istifarroh, I., \& Nugroho, W. C. (2019). Perlindungan hak disabilitas mendapatkan pekerjaan di perusahaan swasta dan perusahaan milik negara. Mimbar Keadilan, 12(1), 278188.

[6] Kaya, S., Kabakci, A. C., \& Dogan, A. A. (2015). Differences in motivation for participating in sports activities according to sport branches. International Journal of Science Culture and Sport, 3(1), 44-53.

[7] Kuranchie-Mensah, E. B., \& Tawiah, A. K. (2016). 
Employee motivation and work performance: a comparative study of mining companies in Ghana Elizabeth. Journal of Industrial Engineering and Management, 21(1-12), 281-289.

[8] Melati, D. L., Minarsih, M. M., \& Fathoni, A. (2016). Pengaruh pendidikan, keterampilan, basic skill terhadap karir untuk keinginan berpindah kerja (Studi Empiris di Kelurahan Jatingaleh Kecamatan Candisari Kota Semarang). Journal of Management, 2(2).

[9] Ndaumanu, F. (2020). Hak penyandang disabilitas: antara tanggung jawab dan pelaksanaan oleh pemerintah daerah. Jurnal HAM, 11(1).

[10] Novandari, W., \& Suliyanto. (2018). Penguatan program creativepreurship untuk kewirausahaan dan program pelatihan berbasis partisipatory training. Prosiding Seminar Nasional Dan Call for Papers "Pengembangan Sumber Daya Perdesaan Dan Kearifan Lokal Berkelanjutan VIII", 474-483.

[11] Nurhayati. (2015). Psikologi pendidikan inovatif. Yogyakarta: Pustaka Pelajar.

[12] Pioh, E. Y., Kandowangko, N., \& Lasut, J. J. (2017). Peran pengasuh dalam meningkatkan kemandirian anak disabilitas netra di Panti Sosial Bartemeus Manado. Acta Diurna, VI(1).

[13] Poerwanti, S. D. (2017). Pengelolaan tenaga kerja difabel untuk mewujudkan workplace inclusion. INKLUSI, 4(1), 1 .

[14] Ratnawati, D., Rufaidah, D., \& Handoyono, N. A. (2019). Pembekalan keterampilan ojek difa city tour untuk mewujudkan kesetaraan kaum disabilitas. Jurnal Pemberdayaan: Publikasi Hasil Pengabdian Kepada Masyarakat, 3(2), 191.

[15] Sembiring, D. (2019). Pengaruh sikap kerja dan motivasi kerja terhadap kinerja dosen di yayasan perguruan nasional medicom. Jurnal Teknik Informatika UNIKA Santo Thomas, 3(2), 108-118.

[16] Slathia, R., Singh, H., \& Dar, H. A. (2015). Motivation among male and female cricket players of Jammu division: A comparative study. International Journal in Physical \& Applied Science, 2(4), 53-56.

[17] Sukadari. (2019). Model pendidikan inklusi dalam pembelajaran anak berkebutuhan khusus. Yogyakarta: Kanwa Publisher.

[18] Sulistyowati, E. (2019). Meningkatkan keterampilan dan hasil belajar bahasa indonesia tentang menulis surat resmi melalui contextual teaching and learning (ctl) pada siswa kelas VI SD 6 Getassrabi. INOPENDAS: Jurnal Ilmiah Kependidikan, 2(1).

[19] Sya'baniah, S. I., Saryono, O., \& Herlina, N. (2019). Pengaruh sikap dan kepribadian terhadap kinerja pegawai (Studi pada Dinas Sosial Kabupaten Ciamis). Business Management and Entrepreneurship Journal, 1(4), 162-177.
[20] Toto. (2018). Pengaruh human resource terhadap prestasi kerja karyawan terhadap KPP Pratama Tasikmalaya. Biormatika: Jurnal Ilmiah Fakultas Keguruan dan Ilmu Pendidikan, 4 (1).

[21] Triutari, I. (2014). Persepsi mahasiswa penyandang disabilitas tentang sistem pendidikan segregasi dan pendidikan inklusi. Jurnal Ilmiah Pendidikan Khusus, 221-229. 